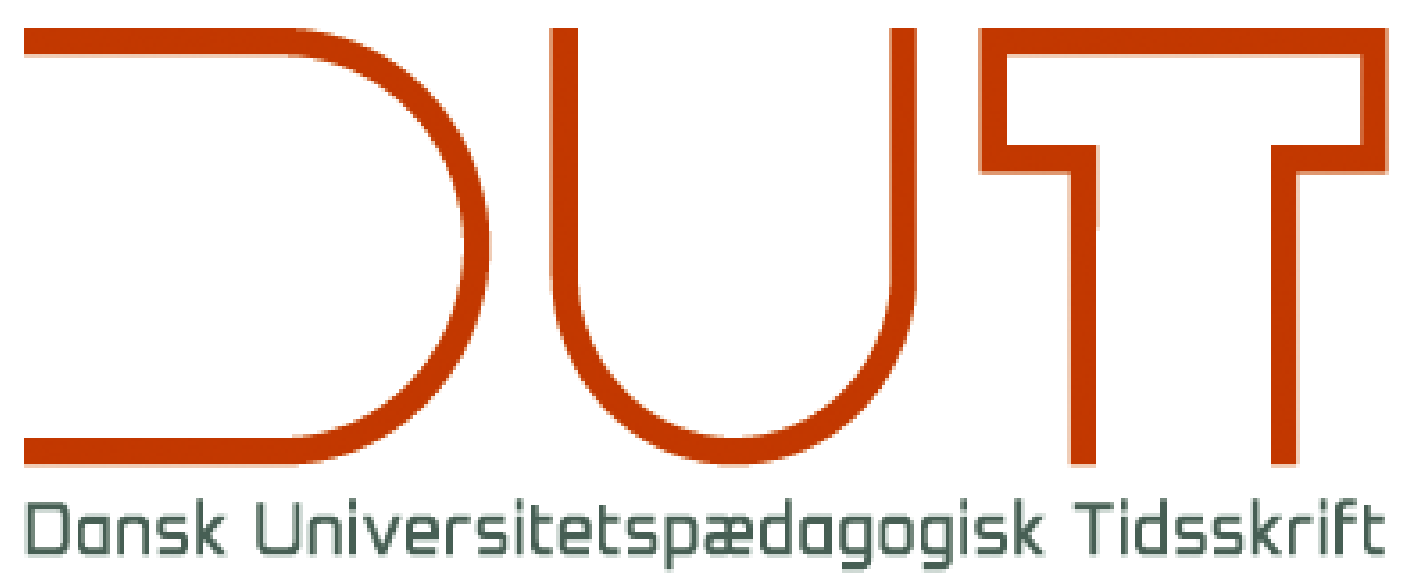

Læringsrum

Årgang 14 nr. 27 / 2019

Titel

Faglige skrivevejledere på studierne - Akademisk skrivning på universitetet

Forfattere

Vibeke Christensen

Sidetal

$20-34$

Udgivet af

Dansk Universitetspædagogisk Netværk, DUN

URL

> http://dun-net.dk/

Betingelser for brug af denne artikel

(C) Copyright
Denne artikel er omfattet af ophavsretsloven, og der må citeres fra den. Følgende betingelser skal dog være opfyldt:

- Citatet skal være i overensstemmelse med "god skik"

- Der må kun citeres „i det omfang, som betinges af formålet“

- Ophavsmanden til teksten skal krediteres, og kilden skal angives ift. ovenstående bibliografiske oplysninger.

DUT og artiklens forfatter 


\title{
Faglige skrivevejledere på studierne - Akademisk skrivning på universitetet.
}

\author{
Vibeke Christensen ${ }^{a, 1}$ \\ Institut for Kulturvidenskaber, Syddansk Universitet
}

Faglig artikel, fagfællebedømt

\begin{abstract}
I denne artikel beskrives en indsats, som har til hensigt at styrke bachelor-studerendes akademiske skriftlighed og faglige socialisering. Det sker gennem inddragelse af faglige skrivevejledere i den skriftlige og skrivedidaktiske praksis i undervisningen. De faglige skrivevejledere er kandidatstuderende på samme uddannelse som de BAstuderende, de skal vejlede, og de deltager indledningsvist $i$ et kursus og varetager derefter vejledning. Indsatsen indgår i et større projekt om Akademisk Skriftlighed på Humaniora på SDU. Indledningsvis beskrives projektet og det samlede forløb. Herefter beskrives skriveindsatser på andre universiteter. Dernæst udfoldes den teoretiske forståelse af akademisk skrivning, som indsatsen baserer sig på. Nærmere beskrivelse af kurset og vejledningen samt evaluering af begge følger derefter. I den afsluttende konklusion reflekteres der over styrker og udviklingsmuligheder i indsatsen.
\end{abstract}

\section{Introduktion}

De universitetsstuderendes skrivefærdigheder eller mangel på samme er med jævne mellemrum emne for offentlig debat. I dagspressen peges der eksempelvis på problemer med sprogforståelse og sproglig korrekthed (Ejsing, 2016) og på mangelfuld argumentation og dokumentation (Drotner, 2015). Kigger man nærmere på forskningen om akademisk skriftlighed, så ligger udfordringen for de studerende måske ikke isoleret i skriftlig korrekthed, men skal ses i sammenhæng med deres overgang fra ét uddannelsesniveau til et andet, hvor de forventes at indgå i og bidrage til en faglig diskurs, som de endnu ikke kender (Drejer, 2018; Sommers \& Saltz, 2004). Arbejdet med akademisk skriftlighed og skrive-kompetence ses i det perspektiv som en praksis, der foregår i en specifik faglig kontekst.

Forsknings- og udviklingsprojektet Akademisk Skriftlighed på Humaniora på Syddansk Universitet (SDU) adresserer bachelorstuderendes udfordringer med akademisk skriftlighed ud fra den forståelse, at akademisk skriftlighed ikke er en isoleret og kontekstløs færdighed, men en social praksis (Lea \& Street, 1998). De studerende skal således ikke blot skrive akademiske tekster, men også tilegne sig og socialiseres ind i faget.

Projekt Akademisk Skriftlighed forløber i perioden 2018-2020. Projektet har til formål at styrke og opkvalificere den skriftlige og skrivedidaktiske praksis på de humanistiske bacheloruddannelser og herigennem støtte de nye studerendes faglige socialisering.

\footnotetext{
${ }^{1}$ Kontakt: vich@sdu.dk
} 
Projektet er tredelt:

1. Kortlægning af omfang og karakter af den skriftlighed, der beskrives i studieordningerne.

2. Uddannelse af faglige skrivevejledere, der efterfølgende skal fungere som vejledere for bachelorstuderende i tilknytning til en konkret disciplin på uddannelsen.

3. Opstilling af et inspirationskatalog baseret på dette projekt samt andre skrivedidaktiske tiltag og praksisformer på uddannelserne.

I denne artikel beskrives projektets 2. del, udviklingsdelen, i form af kurset for de faglige skrivevejledere og deres efterfølgende arbejde med vejledning af bachelorstuderende. Forud for udvikling af kurset og vejledningsforløbet er der foretaget en kortlægning af studieordningernes beskrivelse af akademisk skriftlighed (Christensen, 2018). Denne analyse indgår i vidensgrundlaget for udviklingen af kurset. Kursus- og vejledningsforløbet gennemføres to gange i projektperioden, hvoraf det første gennemløb, der ligger til grund for denne artikel, er gennemført i forårssemestret 2018.

I næste afsnit præsenteres det samlede forløb i form af kursus og vejledningsopgave. Dernæst placeres indsatsen i forhold til andre skriveindsatser på videregående uddannelse. Teoretisk baggrund og begrundelser beskrives i de følgende to afsnit. Herefter følger uddybende beskrivelse af kurset og vejledningsforløbet. Artiklen afsluttes med evaluering og diskussion.

\section{Indsatsen - forløbet i overblik}

Forløbet indledes med et kursus for de faglige skrivevejledere afviklet på tre fortløbende dage. De faglige skrivevejledere er udvalgt af studiet blandt egne kandidatstuderende. De er således nået længere på studiet end de bachelorstuderende, og de er udvalgt af studielederen, fordi de selv er fagligt dygtige akademiske skrivere. Kurset har følgende indhold:

\begin{tabular}{|l|l|l|l|}
\hline Kurset & Dag 1 & Dag 2 & Dag 3 \\
\hline Indhold & Faglig skrivning & $\begin{array}{l}\text { Feedback i skrive- } \\
\text { processer }\end{array}$ & Skrivedidaktik \\
\hline Deltagere & $\begin{array}{l}\text { Faglige } \\
\text { skrivevejledere }\end{array}$ & $\begin{array}{l}\text { Faglige } \\
\text { skrivevejledere }\end{array}$ & $\begin{array}{l}\text { Faglige } \\
\text { skrivevejledere } \\
\text { Underviser(e) på de } \\
\text { involverede } \\
\text { discipliner/fag }\end{array}$ \\
\hline $\begin{array}{l}\text { Praksisnær opgave } \\
\text { til de faglige } \\
\text { skrivevejledere }\end{array}$ & $\begin{array}{l}\text { Analyse af egne og } \\
\text { de øvrige faglige } \\
\text { skrivevejlederes } \\
\text { tekster }\end{array}$ & $\begin{array}{l}\text { Feedback på egne og } \\
\text { de øvrige faglige } \\
\text { skrivevejlederes } \\
\text { tekster }\end{array}$ & $\begin{array}{l}\text { Planlægning af det } \\
\text { kommende } \\
\text { vejledningsarbejde på } \\
\text { disciplinen/faget }\end{array}$ \\
\hline Omfang & 6 timer & 4 timer & 4 timer \\
\hline
\end{tabular}

Figur 1. Oversigt over kursets indhold og deltagere 
Den efterfølgende vejledningsopgave kan ikke varetages efter samme skabelon på alle studier, fordi den skal tilpasses faget og kulturen på disciplinen. Figur 2 viser gennem en oversigt over vejledningsopgaven for de faglige skrivevejledere og de meget forskellige rammer for planlægning af vejledningsopgaven.

\begin{tabular}{|c|c|c|c|c|}
\hline Studie & $\begin{array}{l}\text { Amerikanske } \\
\text { Studier }\end{array}$ & $\begin{array}{l}\text { Designkultur } \\
\text { og Design- } \\
\text { kultur \& } \\
\text { økonomi }\end{array}$ & \multicolumn{2}{|c|}{ Medievidenskab } \\
\hline $\begin{array}{l}\text { Discipliner/fag på } \\
\text { 2. semester }\end{array}$ & 5 discipliner/fag & $\begin{array}{l}4 \text { discipli- } \\
\text { ner/fag }\end{array}$ & \multicolumn{2}{|l|}{4 discipliner/fag } \\
\hline $\begin{array}{l}\text { Discipliner/fag og } \\
\text { hold med faglige } \\
\text { skrivevejledning }\end{array}$ & $\begin{array}{l}1 \text { disciplin/fag } \\
1 \text { hold } \\
\text { ca. } 45 \text { stu- } \\
\text { derende }\end{array}$ & $\begin{array}{l}1 \text { disciplin/fag, } \\
\text { som er fælles } \\
\text { for begge } \\
\text { uddannelser } \\
3 \text { hold } \\
\text { 30-40 stude- } \\
\text { rende pr. hold }\end{array}$ & \multicolumn{2}{|c|}{$\begin{array}{l}2 \text { discipliner/fag, a og b } \\
2 \text { hold } \\
\text { ca. } 80 \text { studerende på det ene hold } \\
\text { og } 120 \text { studerende på det andet }\end{array}$} \\
\hline $\begin{array}{l}\text { Eksamensform i } \\
\text { den/de deltagen- } \\
\text { de discipliner/fag }\end{array}$ & $\begin{array}{l}\text { Portfolio med } \\
\text { to skriftlige } \\
\text { opgaver i løbet } \\
\text { af semestret og } \\
\text { en afsluttende } \\
\text { bunden opgave }\end{array}$ & $\begin{array}{l}\text { Bunden } \\
\text { skriftlig } \\
\text { hjemme- } \\
\text { opgave }\end{array}$ & $\begin{array}{l}\text { Disciplin a } \\
\text { Mundtlig } \\
\text { gruppe- } \\
\text { eksamen med } \\
\text { synopsis }\end{array}$ & $\begin{array}{l}\text { Disciplin b } \\
\text { Fri skriftlig } \\
\text { hjemmeopgave }\end{array}$ \\
\hline $\begin{array}{l}\text { Organisering af de } \\
\text { faglige skrive- } \\
\text { vejledere }\end{array}$ & $\begin{array}{l}3 \text { faglige skrive- } \\
\text { vejledere }\end{array}$ & $\begin{array}{l}5 \text { faglige } \\
\text { skrive- } \\
\text { vejledere } \\
2 \text { tilknyttet ét } \\
\text { hold } \\
3 \text { tilknyttet de } \\
\text { øvrige to hold }\end{array}$ & $\begin{array}{l}2 \text { faglige skrive- } \\
\text { vejledere }\end{array}$ & $\begin{array}{l}2 \text { faglige skrive- } \\
\text { vejledere }\end{array}$ \\
\hline Vejledningsramme & \multicolumn{4}{|c|}{45 timer til hver af de faglige skrivevejledere } \\
\hline
\end{tabular}

Figur 2. Oversigt over rammerne for den vejledning, som første gruppe af faglige skrivevejledere varetog.

De deltagende studier i første gennemløbii er inviteret ud fra et ønske om at repræsentere bredden i bacheloruddannelserne. Bredden angår variation i uddannelsernes genstandsfelt, deres størrelse og deres behandling af akademisk skriftlighed i studieordningerne. Udvælgelsen baserer sig på analysen af studieordningerne og tilgængelige oplysninger om studenteroptaget i 2017. 
Af oversigterne fremgår den terminologi, som anvendes i artiklen. Den samlede bacheloruddannelse betegnes som studiet eller uddannelsen. Hvert semester består af et antal discipliner eller fag. Den faglige skrivevejledning er knyttet til en konkret disciplin.

Det tre dage lange forløb for de kommende faglige skrivevejledere betegnes kurset. Kursusdeltagerne betegnes faglige skrivevejledere. Undervisningen på kurset varetages af projektgruppen og kaldes kursusunderviserne. De faglige skrivevejledere vejleder efterfølgende på én af uddannelsens discipliner/fag på 2. semester. Vejledningen planlægges i tæt samarbejde med underviseren på disciplinen/faget. Bachelorstuderende eller slet og ret studerende betegner de studerende, som modtager faglig skrivevejledning.

Med henblik på at placere den beskrevne indsats i forhold til andre kendte indsatser beskrives i næste afsnit udvalgte skriveindsatser på hovedsageligt danske universiteter.

\section{Skrive-indsatser på danske universiteter og et udblik til USA}

Indsatser vedrørende akademisk skriftlighed varetages på forskellig måde på danske universiteter og forankres på såvel universitetsniveau, fakultetsniveau som studieniveau.

På universitetsniveau tilbydes forskellige ressourcer. Eksempelvis tilbyder Læringszonen, SDU, forskellige kurser, der støtter de studerendes læring, herunder også kurser om sprog og sproglig korrekthed. Sprog og skriftlighed anskues her i et generisk færdighedsperspektiv. Et andet eksempel er Studypedia, som er en digital ressource på Aarhus Universitet (Aarhus Universitet, u.å.). Også denne ressource adresserer studielivet i et bredere perspektiv, hvor digital støtte til opgaveskrivning indgår som et element.

På fakultetsniveau ses forskellige skriveindsatser. Pædagogisk Center ved Samfundsvidenskab på Københavns Universitet tilbyder oprettelse og facilitering af skrivegrupper (Københavns Universitet, u.å.). Ved Aarhus School of Business and Social Sciences er der udarbejdet en model for en fakultetsindsats for udvikling af de studerendes akademiske skrivekompetencer (T. W. Jensen, Bay, \& Andersen, 2017). Modellen adresserer både generel og fagspecifik skrivning. Det centrale tiltag er udvikling af workshops om akademisk skriftlighed i forlængelse af de enkelte fags behov. Disse workshops retter sig især mod studerende, der skriver speciale og bachelorprojekt, men der er også workshops til instruktorer, studievejledere og studerende på tidligere semestre.

På studieniveau beskrives akademisk skriftlighed i studieordningerne, hvor den kan være det centrale indhold i discipliner eller indgå sammen med andet indhold i discipliner. En undersøgelse af studieordningerne på Humaniora på SDU viser, at omfanget og karakteren af den opmærksomhed, som den akademiske skriftlighed får, hænger sammen med uddannelsens genstandsfelt. Tydeligst er opmærksomheden på uddannelser, der har tekster, sprog og evt. skriftlighed som genstandsfelt (Christensen, 2018). Vejledning og feedback er ikke fremtrædende i de analyserede studieordninger på SDU, om end tidligere gennemførte projekter vidner om, at der arbejdes med skriftlighed i praksis (Krogh, 2008). Også på andre universiteter arbejder undervisere og studerende lokalt på studierne med skriftlighed, fx gruppevejledning i forbindelse med opgaveskrivning $(H$. N. Jensen, 2008) og formativ feedback $(H . N$. Jensen, 2008; Laursen, Kayser, \& Kamper-Jørgensen, 2016).

Fra amerikansk videregående uddannelse kendes begrebet skrivetutorer, der som udgangspunkt har været knyttet til centrale skrivecentre og opfattet som besøgende i undervisningen på disciplinerne (Soven, 2001). Soven sammenligner disse skrivetutorer med en anden type 
skrivetutorer, som er indskrevet i curriculum og integreret i undervisningen på disciplinen. De to forskellige praksisser rejser flere spørgsmål: for det første, specialistviden versus generalistviden vedrørende såvel skrivningens form som faglige indhold; for det andet, skrivetutorens rolle i forhold til underviser og studerende; og for det tredje, den studerendes grad af forpligtelse til at modtage skrivevejledning. Driscoll (2015) undersøger uddannelse af skrivetutorer i et transferperspektiv på læring, herunder hvordan kurser for skrivetutorer understøtter både skrivetutorens egen transfer af viden, strategier og færdigheder fra kursus til vejledning, og hvordan de vejledningssøgende på tilsvarende vis overfører viden, strategier og færdigheder på tværs af kontekster. Den beskrevne amerikanske forskning har afsæt i en generisk forståelse af akademisk skriftlighed praktiseret gennem centrale skrivecentre, mens det tiltag, der beskrives i denne artikel, har afsæt i en forståelse af akademisk skriftlighed som fagspecifik og dermed knyttet til disciplinen (Carter, 2007; Lea \& Street, 1998). Frem for at skrive på tværs af kontekster skal vores indsats altså støtte den studerende i at skrive sig ind i sit fag, den faglige diskurs og det faglige fællesskab. Trods de forskellige udgangspunkter, så er spørgsmålene vedrørende både vejledningspraksis og -uddannelse også relevante i forhold til arbejdet med faglige skrivevejledere på SDU. Spørgsmål om den faglige skrivevejleders rolle og autoritet samt den fagspecifikke feedback til de bachelorstuderende tages op i projektets forskningsdel.

\section{Indsatsens teoretiske forankring}

\section{Skriftlighedens rolle og funktioner i højere uddannelse}

Bag formålet med projektet ligger en antagelse om, at akademiske skrivekompetencer er væsentlige forudsætninger for at gennemføre en akademisk uddannelse. I dette afsnit beskrives og begrundes denne forståelse.

Curry og Lillis (2003) angiver, at de studerendes akademiske skrivning er helt central, men ofte usynlig, i undervisning og læring:

Student academic writing continues to be at the centre of teaching and learning in higher education, but is often an invisible dimension of the curriculum; that is, the rules or conventions governing what counts as academic writing are often assumed to be part of the 'common sense' knowledge students have, and are thus not explicitly taught within disciplinary courses (Curry \& Lillis, 2003:3)

Det centrale skyldes, at skrivning tjener flere formål i højere uddannelse, nemlig uddannelsesinstitutionens vurdering af den studerende, den studerendes loering og den studerendes adgang til det faglige miljø. Skriftligheden tjener med andre ord et læringsformål samtidig med, at den også er en betingelse for eller en gate til optagelse i det faglige miljø.

De studerendes mulighed for at tilegne sig akademiske skrivekonventioner er udfordret af forandringer i uddannelseskonteksten, bl.a. øget studenteroptag, øget diversitet i studenterforudsætninger og - baggrund og komplekse deltagelsesmønstre i form af eksempelvis flere deltidsstuderende og fjernstuderende. I Danmark tillægges også fremdriftsreformens krav om hurtig gennemførelse betydning for vilkårene for de studerendes arbejde med akademisk skrivning (Andersen, Bay, \& Wirenfeldt Jensen, 2017). I dansk kontekst bekræftes de studerendes udfordringer med udvikling af akademisk skrivekompetence i Holm og Clemensens (2017) undersøgelse fra DPU og af Kristiansens erfaringer som skrivekonsulent på Københavns Universitet (Kristiansen, 2017). På danske universiteter har det medført forskellige tiltag. 


\section{Forståelsen af akademisk skriftlighed}

En overordnet forståelse af akademisk skriftlighed og teoretisk ramme for indsatsen er den britiske Academic Literacies-tilgang, der beskriver tre forskellige forståelser af akademisk skrivning (Lea \& Street, 1998):

1. Study skills, hvor skrivning ses som en teknisk og instrumentel færdighed, der kan overføres mellem kontekster. Manglende succes med skrivningen tillægges den studerendes mangler.

2. Academic socialisation, hvor skrivning ses som et medium for repræsentation inden for en relativt homogen akademisk kultur. Succesfuld skrivning indebærer den studerendes tilpasning til den akademiske diskurs.

3. Academic literacies, hvor skrivning ses som en social praksis, der vedrører såvel erkendelsesspørgsmål som identitets- og magtforhold. Skrivning er en kontekstbundet meningsskabende proces. Succesfuld skrivning omfatter forhandling af mening inden for den sociale praksis, herunder forhandling af fx kommunikative former som indhold og genre.

De tre perspektiver ses hverken som gensidigt udelukkende kategorier eller som lineær udvikling, men som diskursive konstruktioner af skriftlighed, der indebærer forskellige tilgange til arbejdet med skriftlighed og med de studerende som skrivere. I praksis vil study skillsforståelsen være indlejret i academic socialisation-forståelsen og begge i academic literaciesforståelsen. Det bevirker, at den forhandling af mening, som kendetegner academic literaciespositionen, også omfatter elementer af kendskab til konventioner i den kultur, som man skriver ind i, samt viden om formelle aspekter ved skriftlighed.

Den studerende skriver sig med andre ord ind i en akademisk diskurs, som for det første er fagspecifik, og som for det andet aktualiserer bestemte opfattelser af akademisk skrivning og af de studerende som skrivere. At lære sig at skrive fagets tekster vil samtidig være at lære sig faget. Den faglige diskurs manifesterer sig på forskellig vis i teksten, ikke bare i terminologi, men også mht. erkendelsesinteresser, hensigt, indhold, struktur og argumentation (Shanahan \& Shanahan, 2012) $)^{i i i}$.

Universiteterne må på denne baggrund påtage sig opgaven at give de studerende mulighed for både at lære sig faget og at skrive fagets tekster (se fx Carter, Ferzli, \& Wiebe, 2007; Kristiansen, 2017). Der er med Prior og Bilbros ord tale om en indkultureringsproces, der omfatter kontekstbundet meaning-making, discipline-making og people-making (Prior \& Bilbro, 2012:25).

\section{Praksis: beskrivelse af det gennemførte forløb}

Uddannelse af de faglige skrivevejledere er udbudt på fakultetsniveau, og vejledningsdelen tilpasses rammerne på de enkelte studier. I det foreliggende projekt er indsatsen knyttet til en konkret disciplin på studiet, hvorved udviklingen af skrivekompetencer sker inden for den faglige ramme og de faglige mål, som gælder for disciplinen. Der er imidlertid intet til hinder for, at studierne kan vælge at knytte de faglige skrivevejledere til flere discipliner. De faglige skrivevejledere samarbejder med underviseren om at definere opgave og rammer for skrivevejledningen. Faglig skrivevejledning tilbydes alle studerende på den deltagende disciplin/fag. Hvorvidt tilbuddet er obligatorisk for den studerende, afhænger af kravene i studieordningen og af undervisningens organisering på den enkelte disciplin. 
Tilknytningen til de faglige miljøer tilgodeses gennem de faglige skrivevejlederes eget medlemskab. De er dermed fortrolige med og bidrager selv til den faglige diskurs, som de skal støtte bachelorstuderende i at skrive sig ind i. Imidlertid kan denne fortrolighed være intuitiv og tavs, og den må gøres synlig for de faglige skrivevejledere, så de kan bruge den i en vejledningssituation. Samtidig har de brug for viden om feedback, vejledning og skrive-didaktik. Det skrivefaglige fundament for at vejlede BA-studerende får de på kurset, der afvikles over tre sammenhængende dage.

\section{Kurset for de faglige skrivevejledere}

I dette afsnit beskrives det kursus, som blev gennemført i januar 2018. På kurset deltog elleve kandidatstuderende fra Medievidenskab, Amerikanske studier og Designkultur/Designkultur og økonomi. Kurset blev evalueret af deltagerne ved afslutningen af den tredje kursusdag.

Det overordnede formål med kurset var at støtte de faglige skrivevejledere i at blive dygtige til at vejlede bachelorstuderende. Kurset var tilrettelagt ud fra et didaktisk princip om tæt sammenhæng mellem teori og praksis. Deltagerne blev således præsenteret for teori og forskningsresultater vedrørende de tre temaer faglig skrivning, feedback og skrivedidaktik, og dernæst arbejdede de praksisnært med stoffet.

Faglig skrivning var temaet for første kursusdag. Målet var, at deltagerne skulle opnå viden om, hvad faglig skrivning er; hvad der kendetegner skriftlighed og tekster i eget fag og endelig viden om forhold af betydning for studerendes udvikling af faglige skrivekompetencer.

Gennem oplæg og diskussion præsenterede vi deltagerne for en forståelse af skrivning som fagspecifik (Shanahan \& Shanahan, 2012) og situeret. Shanahan og Shanahan nævner som eksempel forskelle på terminologi inden for naturvidenskab og historie. Groft sagt skal naturvidenskabelige begreber bruges til klassificering, hvorfor de er præcise og informationstætte. Begreber i historie skal bruges til at beskrive sammenhænge og må derfor være beskrivende og eventuelt metaforiske.

Med henblik på at komme tæt på teksten præsenterede vi Dysthe, Hertzberg og Hoels (2001) teksttrekant, der viser, at tekstarbejdet foregår på fem niveauer. På første niveau arbejder skriveren med bevidsthed om skrivekultur, kontekst, formål med skrivningen, genre og intenderet modtager, det vil sige hele skrivesituationen. Tekstens indhold og struktur er i fokus på andet niveau. Der fokuseres på kundskab om emnet, fx selektion af indhold, samt kundskab om og færdighed $i$ at strukturere teksten, fx relevante fremstillingsformer. På tredje niveau rettes blikket mod sætningen, herunder viden om og kompetence $i$ sætningsopbygning og kobling af sætninger. Ordvalget er det centrale på fjerde niveau, eksempelvis valg af faglige termer og variation i ordvalg. Det femte og sidste niveau angår retskrivning, tegn, referencer, formalia. Skrivekompetence angår alle tekstens niveauer fra det globale til det lokale. 


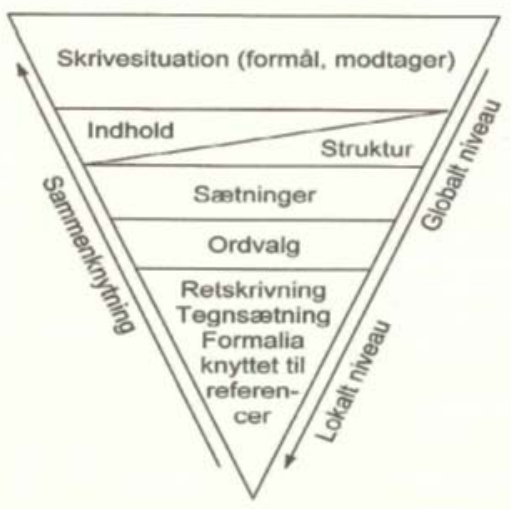

Figur 3: Teksttrekanten (Dysthe, Hertzberg og Hoel, 2001:42) @ Forlaget Klim

Det var vigtigt, at de faglige skrivevejledere blev opmærksomme på, at teksten omfatter flere niveauer, som man i skriveprocessen hopper frem og tilbage mellem, men som dog er indbyrdes afhængige forstået således, at valg på ét niveau påvirker mulighederne på de øvrige. Endvidere skulle de blive opmærksomme på, at de valg, man foretager, hænger sammen med den faglige diskurs, man skriver i.

Den specifikt akademiske skrivning blev præsenteret med de fire domæner, som kendetegner diskursfællesskabet: faget, skriveprocessen, genrerne og retorikken (Beaufort, 2007 her efter Kristiansen, 2017). Endelig beskrev vi med Sommers og Saltz (2004) den bachelorstuderendes udvikling fra novice til ekspert.

Faglige diskurser er dynamiske og lader sig ikke beskrive udtømmende, dels fordi de er omfattende, dels fordi de vedvarende forhandles i det faglige fællesskab. De faglige skrivevejledere kan altså på den ene side ikke udstyres med en skabelon for, hvordan man skriver en faglig tekst inden for deres felt, men på den anden side har de brug for en retning. Teksttrekanten kom til at udgøre et tænkeredskab, der både var tilstrækkeligt konkret til at støtte deres efterfølgende analyse af tekster og tilstrækkeligt rummelig til at kunne omfatte de forskellige faglige diskurser, som karakteriserede de forskellige uddannelser, der var repræsenteret på kurset.

Meget væsentligt for de faglige skrivevejlederes erkendelse af akademisk skriftlighed som fagspecifik var deres arbejde med analyse af studentertekster fra forskellige studier. Alle deltagere havde bidraget med en anonymiseret udgave af en tekst fra den disciplin, de skulle vejlede på. Teksterne var gjort tilgængelige forud for kurset, og alle studerende havde læst eget bidrag og en tekst fra hver af de to øvrige studier. Den første og meget øjenåbnende opgave var at sammenligne teksten fra eget studie med tekster fra de andre studier. Således bevidstgjort om forskelle i de faglige diskurser, dykkede de ned i egne tekster med henblik på at beskrive det karakteristiske ved eget fags diskurs.

Den afsluttende fælles opsamling synliggjorde yderligere karakteristika for de studerende. Vi vurderer på baggrund af iagttagelser og evalueringer, at det komparative perspektiv var afgørende for, at erkendelsen af de særlige faglige karakteristika kunne opnås på kursets relativt korte tid.

Feedback i skriveprocesser var temaet for anden kursusdag. Det var målet, at deltagerne skulle opnå viden om feedback, herunder muligheder og udfordringer, med henblik på at kunne 
træffe kvalificerede valg i deres videre arbejde med skrivevejledning. Desuden skulle de stifte bekendtskab med at give feedback på alle niveauer i teksttrekanten.

I præsentationen af feedback trak vi på kognitiv og sociokulturelt orienteret feedbackforskning. Vi præsenterede deltagerne for nødvendigheden af, at den lærende kender enten målet for eller intentionen med den akademisk skrivning (Black \& Wiliam, 2009; Hattie \& Timperley, 2007). Med begrebet kvalitetskriterier blev de introduceret til arbejdet med at specificere forventninger til og vurdering af en opgavebesvarelse, og at give feedback i forhold til disse kriterier. Viden om opgave-, proces- og selvreguleringsfeedback indgik sammen med opmærksomhed på forskellene mellem formativ og summativ feedback og vurdering. En væsentlig pointe var præsentation af forskningsresultater, der viser, at feedbackmodtageren ikke bruger al den feedback, han får tilbudt. Deltagerne blev præsenteret for muligheder og begrænsninger ved peer-feedback. Endelig indgik principper for god feedback på skriftlige opgaver også (Kvithyld \& Aasen, 2013).

Deltagernes praksisnære arbejde knyttede sig igen til deres egne tekster, hvor de først skulle forsøge sig med at opstille kvalitetskriterier og dernæst bruge dem til at give feedback på egen eller en kursuskammerats tekst ud fra de opstillede kvalitetskriterier og med brug af teksttrekanten og deres viden om feedbackniveauer. Ifølge evalueringerne fungerede opgaven for alle - for nogle af de faglige skrivevejledere, som bidrog med egne tekster, blev det ovenikøbet en øjenåbner for, hvor meget de selv havde udviklet sig skriftligt og fagligt siden de første semestre på bacheloruddannelsen.

Skrivedidaktik og praktisk planloegning var temaet for sidste kursusdag. Det var målet, at deltagerne opnåede viden om skriveprocessen og didaktiske tiltag, der kunne støtte den, og at de fik mulighed for at reflektere over og diskutere muligheder for faglig skrivevejledning $\mathrm{i}$ den disciplin, hvor de skulle vejlede. Endelig skulle dagen munde ud i planlægning af forårets faglige skrivevejledning på studierne.

Dagens indhold baserede sig på Dysthe, Hertzberg og Hoels forståelse af skriveprocessen som en udvikling fra idé til færdig tekst og en udvikling fra store træk i teksten til detaljer (2001:42). De faglige skrivevejledere stiftede bekendtskab med faser i skriveprocessen og skrivedidaktiske modeller, herunder også udfordringer med og redskaber til at komme i gang med skrivningen. Ligeledes blev de præsenteret for metoder til at færdiggøre teksten. Dette med henblik på at sætte dem i stand til at vejlede ikke blot på teksten, men også på skriveprocessen. Desuden indgik der denne dag en kort opsamling af hovedpointerne fra de to første dage, da underviserne på disciplinerne også deltog.

Det praksisnære arbejde denne dag bestod i planlægning af semestrets skrivevejledningsopgave i samarbejde med underviseren på disciplinen. Da indsatsen jo er fagspecifik, gives der ingen skabelon for, hvordan skrivevejledningsopgaven skal planlægges, hvilket også fremgår af figur 2. Kursusunderviserne stillede sig til rådighed som sparringpartnere i planlægning af skrivevejledningsforløb. I næste afsnit præsenteres forhold af væsentlig betydning for den konkrete planlægning.

\section{De faglige skrivevejlederes vejledningsopgave}

I det gennemførte forløb har alle faglige skrivevejledere haft 45 timer til rådighed til vejledning uanset holdstørrelse på BA-disciplinen. Dermed har timetallet været en rammesættende faktor for, hvordan et skrivevejledningsforløb kunne tilrettelægges på disciplinen. På længere sigt kan denne tidsramme differentieres, så det bliver skrivevejledningens indhold, der defi- 
nerer strukturen i forløbet frem for tidsrammen. Den faste tidsramme har imidlertid været produktiv $i$ et udviklingsperspektiv, fordi den har foranlediget en mangfoldighed af måder at organisere skrive- og vejledningsopgaver og vist en vifte af forskellige tilbud til de bachelorstuderende.

Frem for at beskrive flere meget forskellige forløb, beskrives i dette afsnit generelle forhold, som tydeligt har haft indflydelse på den måde, som vejledningsforløbet på disciplinerne/fagene har været planlagt og gennemført.

Holdstørrelsen er afgørende for, hvordan skrivevejledningen organiseres. Studierne knyttede to eller tre faglige skrivevejledere til hvert hold. På hold med op til ca. 45 BA-studerende blev der planlagt individuel vejledning, mens skrivevejledningen på større hold blev organiseret som vejledning på gruppeopgaver. Der var fordele ved begge varianter. Den individuelle vejledning gjorde det muligt at komme helt tæt på den enkelte bachelorstuderendes succeser, udfordringer og skriveudvikling. Feedbacken havde en klar adressat. På større hold blev der i stedet arbejdet med gruppeopgaver. Gruppevejledningen kom knapt så tæt på den enkelte studerendes skriftlighed, men til gengæld lå der potentielt læringsmuligheder gemt i de diskussioner om skrivningen, som fandt sted i gruppen forud for aflevering af et skriftligt udkast eller færdigt produkt. I begge varianter indgår den studerende i en diskursiv praksis i samtalen med den faglige skrivevejleder, mens gruppevarianten også etablerer gruppesamtalen som en diskursiv praksis.

Eksamensformen på disciplinen havde stor indflydelse på den gennemførte vejledning. Der kan grundlæggende skelnes mellem skriftlige og mundtlige eksamener. Der findes flere varianter af den skriftlige eksamen. For discipliner med portfolioeksamen gav organiseringen næsten sig selv, idet de faglige skrivevejledere kunne knyttes til de bachelorstuderendes arbejde med de produkter, som blev samlet i portfolioen. På discipliner med bunden skriftlig opgave som eksamensform så vi forskellige varianter. Én realiseret mulighed var at lade holdet arbejde med en opgave, der lignede eksamensopgaven. De faglige skrivevejledere støttede skriveprocessen gennem tilrettelæggelse og gennemførelse af workshops, hvor de også faciliterede peer-feedback. I nogle tilfælde var der mulighed for både løbende og afsluttende feedback, i andre kun løbende. En anden realiseret mulighed var at lade de bachelorstuderende udarbejde små artikler om hvert af de faglige emner, som disciplinen omfattede. Disse små artikler blev organiseret i en wiki eller i et samlet dokument, der kunne udgøre et opslagsværk for den bachelorstuderende i den ofte tidspressede skriveperiode for en bunden skriftlig eksamensopgave. I denne variant var workshops omdrejningspunkt for skrivning og vejledning, men der var også mulighed for feedback på andre tidspunkter, hvis de studerende opsøgte den.

På discipliner med mundtlig eksamen viste der sig forskellige muligheder. I fag med en synopsiseksamen vejledte de faglige skrivevejledere de studerende i deres arbejde med synopsen. På én disciplin var der til hver undervisningsgang planlagt en studenterpræsentation af et emne eller en artikel. Forud for denne præsentation udarbejdede gruppen et talepapir, som de faglige skrivevejledere gav feedback på i god tid inden præsentationen.

Feedbackformen - skriftlig eller mundtlig - har også betydning for organiseringen. Skriftlig feedback har været den dominerende feedbackform. De studerende sendte spørgsmål eller tekstudkast til de faglige skrivevejledere på mail, og de gav feedback enten på mail eller som kommentarer $i$ et vedhæftet dokument. Denne form var fleksibel for alle parter. Den 
mundtlige feedbackform blev enten praktiseret i forbindelse med workshops, som fælles feedback til holdet eller som opfølgende individuel samtale på skriftlig feedback. Især workshops og opfølgende samtale gav det dialogiske aspekt gode vilkår, men den er naturligvis mindre fleksibel for alle parter.

Vedvarende samarbejde mellem faglige skrivevejledere og underviseren viste sig at være væsentlig. I de fleste tilfælde aftalte underviseren og de faglige skrivevejledere kvalitetskriterier for opgavebesvarelsen på den sidste kursusdag, men adgangen til underviseren i løbet af semestret var også nødvendig. De fleste mødtes naturligt et par gange i løbet af semestret, fx i forbindelse med workshops eller præsentation af en ny opgave. Derudover havde man typisk en stående aftale om mailkontakt, hvis der opstod behov.

\section{Resultater - evaluering af forløbet}

Det gennemførte forløb har omfattet elleve faglige skrivevejledere (én havde dobbelt vejledning), fem undervisere og omkring 250 bachelorstuderende. Kurset er evalueret skriftligt af de faglige skrivevejledere ved besvarelse af åbne spørgsmål. Efter vejledningsforløbet er der gennemført interviews med alle faglige skrivevejledere, alle undervisere og enkelte bachelorstuderende fra hver af de involverede discipliner. Interviewene er foretaget med henblik på forskning, men omfatter også spørgsmål af evaluerende karakter, som inddrages i den samlede evaluering af forløbet.

I et overordnet perspektiv har forløbet fået positiv evaluering af alle deltagere. De faglige skrivevejledere evaluerer kurset særdeles positivt. Underviserne på disciplinerne er enige om, at de faglige skrivevejledere yder et kvalificeret stykke arbejde, som de selv har vanskeligt ved at nå, og de bachelorstuderende, der har tage imod tilbuddet om faglig skrivevejledning, udtrykker for hovedpartens vedkommende tilfredshed og positivt udbytte. Evalueringen uddybes nedenfor, hvor der også peges på udfordringer og forhold, der bør justeres eller undersøges nærmere.

Kurset vurderes at have lykkedes med at kvalificere de faglige skrivevejledere til vejledningsopgaven. Evalueringen af kurset, der blev foretaget inden de faglige skrivevejledere havde vejledt på disciplinerne, viste det, og vurderingen fastholdes i de interviews med de faglige skrivevejledere, som blev gennemført, efter deres vejledningsopgave var afsluttet. Silas siger:

En kommentar i forhold til kurset, som jeg også synes var virkelig vitalt for mig, det var ... jeg synes, det var rigtig rart at få at vide, hvad de andre fagdiskurser på de andre discipliner [fag] indeholdt, altså hvad det ville sige at skrive en opgave for dem. For jeg fandt ud af, at det var meget anderledes at skrive en opgave på de forskellige fag. Og det synes jeg styrkede min egen viden om, hvad definerer så en Medievidenskabsopgave, fordi ved at vide hvad de andre er, ved du også mere om, hvad der sådan består i din opgave, hvad der skal vare med i din opgave inden for din fagdiskurs. Det synes jeg har hjulpet mig rigtigt meget at vide hvordan - altså kunne determinere, bare hvordan en medievidenskabsopgave ser ud frem for andre slags opgaver (Silas, faglig skrivevejleder på Medievidenskab)

De interviewede bachelorstuderende giver gennemgående udtryk for, at de har draget nytte af den faglige skrivevejledning. En studerende fortæller, hvordan han brugte feedbacken på første portfolioopgave i den anden opgave, hvilket ud over øget viden og indsigt også gav sig konkret udtryk i, at underviseren bedømte den anden opgave bedre end den første. 
To studerende på Medievidenskab nævner de faglige skrivevejledere som bindeled mellem dem og underviseren. Konkret beskriver de, at de præsenterer deres tekst for de faglige skrivevejledere og reviderer den på baggrund af deres feedback, inden de præsenterer den for underviseren. Alternativt henvender de sig til de faglige skrivevejledere, hvis de har fået feedback fra underviseren, som de ikke forstår. En tilsvarende medierende funktion udtrykker en bachelorstuderedende på Designkultur og økonomi:

Jamen jeg tror bare det der med, at man føler sig så meget mere relaterbar i forhold til dem [de faglige skrivevejledere, Vibeke Christensen] - altså de kan virkelig hurtigt scette sig $i$ ens sted, og jeg ved godt, at underviseren prøver også på det, men de er jo bare så langt akademisk henne, at vi er der slet ikke, så det føles nogen gange $S \AA$ uoverskueligt Uulie, bachelorstuderende på Designkultur og økonomi)

Imidlertid er det værd at bemærke, at det netop er studerende, der har benyttet sig af tilbuddet om skrivevejledning, som har meldt sig til interview, og billedet kan derfor ikke tages til indtægt for samtlige bachelorstuderendes opfattelse og udbytte. Udfordringen med at få alle til at opsøge feedback, hvis den er frivillig, er velkendt (nævnes fx af Soven, 2001 - se ovenfor) og peger på et behov for at gøre faglig skrivevejledning obligatorisk, fx gennem justering af studieordningen og/eller den didaktiske tilrettelæggelse af akademisk skriftlighed i undervisningen.

Én af de faglige skrivevejledere har i et enkelt tilfælde oplevet sin autoritet som beklikket af en studerende. Episoden nævnes både af underviseren og den faglige skrivevejleder selv $\mathrm{i}$ interviews. Denne hændelse aktualiserer spørgsmålet om den faglige skrivevejleders rolle og position mellem underviser og studerende, som Soven (2001 - se ovenfor) peger på. De faglige skrivevejledere har autoritet i kraft af, at de er længere i studiet end de studerende. Men de er selvfølgelig ikke lige så vidende og indsigtsfulde som underviseren, hvilket også fremgår af Julies betragtning ovenfor. De faglige skrivevejledere er også tillagt autoritet af studiet, der jo netop har udvalgt dem til opgaven, fordi de selv er dygtige skrivere/studerende. Men den dimension er ikke nødvendigvis kendt af de studerende. Endelig låner de autoritet fra den underviser, som de samarbejder med. Selv med omhyggelig opmærksomhed på alle disse aspekter af autoriteten, så kan man (også som underviser) komme ud for kritiske studerende, og samarbejdet mellem faglige skrivevejledere og underviser(e) er derfor af stor betydning. Det er forhold, som bør undersøges nærmere, herunder fx de faglige skrivevejlederes inddragelse af deres faglige og pædagogiske viden.

\section{Konklusion}

At lære sig at skrive fagets tekster er samtidig at lære sig faget. Skriftlighed er altså både et mål i sig selv og et middel for læring. Endelig er skriftlighed en adgang til det faglige fællesskab. Universiteterne må påtage sig opgaven at give de studerende mulighed for både at lære sig faget og at skrive fagets tekster (se fx Carter et al., 2007; Kristiansen, 2017). Opgaven adresseres på forskellige vis på universitets-, fakultets- og studieniveau på de danske universiteter. Indsatsen med uddannelse af faglige skrivevejledere på Humaniora på SDU knytter an til både fakultet og studie, idet kurset udbydes på fakultetsniveau og de faglige skrivevejlederes vejledningsopgave udføres studie- og endog disciplinspecifikt. Med inddragelse af ældre studerende i vejledningen af bachelorstuderende sikres tilknytningen til det faglige miljø, men samtidig rejser det spørgsmål om dybden af deres indsigt i faget og i akademisk skriftlighed. 
Det faglige vidensniveau sikres på studierne. Først og fremmest sker det gennem omhyggelig udvælgelse af de faglige skrivevejledere baseret på undervisernes kendskab til dem. Dernæst sker det i samarbejdet med underviseren i det fag, som de skal vejlede på. Dels vil der i planlægningen af forløbet indgå faglige diskussioner, der kvalificerer den viden, som de faglige skrivevejledere i forvejen besidder, dels kan der aftales mulighed for, at de faglige skrivevejledere er til stede sammen med de bachelorstuderende i dele af undervisningen, hvis det skønnes hensigtsmæssigt. De bachelorstuderende anerkender i udstrakt grad de faglige skrivevejlederes faglighed. For flere studerende har de faglige skrivevejledere vist sig som overkommelige faglige rollemodeller. Således bidrager de faglige skrivevejledere til de nye studerendes socialisering ind i faget - forhold, som vi vil undersøge yderligere i projektets forskningsdel. En enkelt studerende har beklikket en faglig skrivevejleders faglighed. I denne sammenhæng er underviserens opbakning af afgørende betydning.

Viden om fagspecifik akademisk skriftlighed sikres gennem kurset. Evalueringer og erfaringer viser, at kurset i høj grad bidrager til, at de faglige skrivevejledere opnår viden om og erkender skriftlighed som fagspecifik, ligesom de også får øje på det fagspecifikke skriftsprog på eget studie og i egne tekster. Hertil er arbejdet med deres egne tekster helt afgørende, først og fremmest som øjenåbner for de faglige skrivevejledere selv, men også som kilde til indsigt i de forskellige fagligheder for kursusunderviserne. I undervisningen åbner kursusunderviserne emnet fagspecifik akademisk skriftlighed med nedslag i studenter-teksterne, mens yderligere uddybning sker dialogisk med deltagerne.

Tre elementer er afgørende for, at de faglige skrivevejledere kan bidrage til at styrke skriveog skrivedidaktisk praksis:

1. Udvælgelsen af de faglige skrivevejledere på studierne

2. Kursets indhold og arbejdsformer

3. Undervisernes og de faglige skrivevejlederes fælles planlægning af vejledningen

Tre andre forhold opfordrer til yderligere overvejelser og undersøgelse. Det første forhold angår, hvordan tilbuddet om faglig skrivevejledning kan komme alle studerende til gavn. Den faglige skrivevejledning benyttes ikke af alle bachelorstuderende i den beskrevne praksis, hvilket den fortsatte indsats vil have opmærksomhed på. En mulighed er at gøre vejledningen obligatorisk gennem indskrivning i studieordningen, en anden at planlægge undervisningen således, at det bliver et indlysende tilvalg eller et umuligt fravalg for de bachelorstuderende. Det andet forhold til nærmere undersøgelse er de faglige skrivevejlederes position mellem underviser og bachelorstuderende. Det tredje og sidste omhandler indsatsens relation til øvrige skrivetilbud af mere generisk art med henblik på at udnytte de samlede tilgængelige ressourcer bedst muligt.

Trods de nævnte forbehold tyder evalueringerne dog på, at de faglige skrivevejledere støtter både akademisk skrivning smalt forstået og akademisk skrivning som middel til læring, lige som der ses tegn på, at dette arbejde støtter de nye studerende i arbejdet med at blive optaget i det faglige fællesskab. 


\section{Referencer}

Andersen, P., Bay, G., \& Wirenfeldt Jensen, T. (2017). Udvikling af studerendes akademiske skrivekompetencer : en model for en indsats på fakultetsniveau. Ledelse, udvikling og overlevelse på universitetet, 12(22).

http://ojs.statsbiblioteket.dk/index.php/dut/article/download/24232/22585

Black, P., \& Wiliam, D. (2009). Developing the theory of formative assessment. Educational Assessment, Evaluation and Accountability, 21(1), 5-31.

Carter, M. (2007). Ways of knowing, doing, and writing in the disciplines. College Composition and Communication, 385-418.

Carter, M., Ferzli, M., \& Wiebe, E. N. (2007). Writing to learn by learning to write in the disciplines. Journal of Business and Technical Communication, 21(3), 278-302.

Christensen, V. (2018). Akademisk skriftlighed: analyse af studieordningerne på Humaniora på Syddansk Universitet. Institut for Kulturvidenskaber Syddansk Universitet: Syddansk Universitet. Institut for Kulturvidenskaber.Curry, M., \& Lillis, T. (2003). Issues in academic writing in higher education. Teaching academic writing, 1-18.

Drejer, S. N. (2018). Overgange og udviklinger: to skriveres transition mellem gymnasium og universitet i fagene dansk og fysik. Odense: Det Humanistiske Fakultet, Syddansk Universitet.

Driscoll, D. L. (2015). Building connections and transferring knowledge: The benefits of a peer tutoring course beyond the writing center. The Writing Center Journal, 153-181.

Drotner, K. (2015). Studerende må altså lære at skrive. Politiken. Retrieved from https://politiken.dk/debat/art5565463/Studerende-m\%C3\%A5-alts\%C3\%A51\%C3\%A6re-at-skrive

Dysthe, O., Hertzberg, F., \& Hoel, T. L. (2001). Skrive for at loere: faglig skrivning i de videregående uddannelser (Vol. 15). Århus: Klim.

Ejsing, J. (2016). Censorer slår alarm: Fagligheden falder på universiteterne. Berlingske Tidende. Retrieved from https://www.b.dk/nationalt/censorer-slaar-alarmfagligheden-falder-paa-universiteterne

Hattie, J., \& Timperley, H. (2007). The power of feedback. Review of Educational Research, 77(1), $81-112$

Holm, L., \& Clemensen, N. (2017). At lære sig" de kloge damers" sprog: Studerendes perspektiver på akademisk skrivning. Dansk Universitetspoedagogisk Tidsskrift, 12(23), 37-51.

Jensen, H. N. (2008). Ja tak til mere kollektiv opgave-og skrivevejledning! Dansk Universitetspoedagogisk Tidsskrift, 3(6), 15-20.

Jensen, T. W., Bay, G., \& Andersen, P. (2017). Udvikling af studerendes akademiske skrivekompetencer-en model for en indsats på fakultetsniveau. Dansk Universitetspoedagogisk Tidsskrift, 12(22).

Kristiansen, B. (2017). Om at skrive på universitetet. Odense: Syddansk Universitetsforlag. 
Krogh, E. (2008). Akademisk skriftlighed: Et udviklingsprojekt for studerende og undervisere på Syddansk Universitet Kolding. Evalueringsrapport maj 2008. Kolding: Syddansk Universitet. Institut for Filosofi, Pædagogik og Religionsstudier

Kvithyld, T., \& Aasen, A. J. (2013). Fem teser om funktionel respons på elevtekster. In J. Smidt, R. Solheim, \& A. J. Aasen (Eds.), På sporet af god skriveundervisning - en bog for loerere $i$ alle fag. Aarhus: Klim.

Laursen, K. Å., Kayser, L., \& Kamper-Jørgensen, M. (2016). Formativ feedback styrker skriftlighed hos studerende fra It og Sundhed. Dansk Universitetspcedagogisk Tidsskrift, 11(21), 147-157.

Lea, M. R., \& Street, B. V. (1998). Student writing in higher education: An academic literacies approach. Studies in Higher Education, 23(2), 157-172.

Prior, P., \& Bilbro, R. (2012). Academic enculturation: Developing literate practices and disciplinary identities. In M. Castelló \& C. Donahue (Eds.), University writing. Selves and texts in academic societies (pp. 19-32): Emerald Group Pub. Ltd.

Shanahan, T., \& Shanahan, C. (2012). What is disciplinary literacy and why does it matter? Topics in language disorders, 32(1), 7-18.

Sommers, N., \& Saltz, L. (2004). The novice as expert: Writing the freshman year. College Composition and Communication, 124-149.

Soven, M. (2001). Curriculum-based peer tutors and WAC. In S. H. McLeod, E. Miraglia, M. Soven, \& C. Thaiss (Eds.), WAC for the new millennium: Strategies for continuing writingacross-the-curriculum programs (pp. 200-232). Illinois: National Council of Teachers of English.

Aarhus Universitet (u.å.). AU Studypedia. Lokaliseret 22. juni 2018 på http://studypedia.au.dk/

\footnotetext{
i Projektet varetages af en projektgruppe bestående af Ellen Krogh, Peter Hobel, Anke Piekut, Søren Nygaard Drejer og Vibeke Christensen. Sidstnævnte har hovedansvaret for udførelsen.

ii Alle uddannelser på Humaniora er inviteret til at deltage i det andet forløb. Seks studier deltager med mellem en og fem faglige skrivevejledere.

iii Shanahan og Shanahan beskriver faglig læsning. Da projektet forstår skriftlighed i et literacyperspektiv, hvor læsning og skrivning anskues som to forbundne sider af arbejdet med skriftsprog, kan viden om receptivt arbejde også anvendes i forbindelse med det produktive arbejde
} 